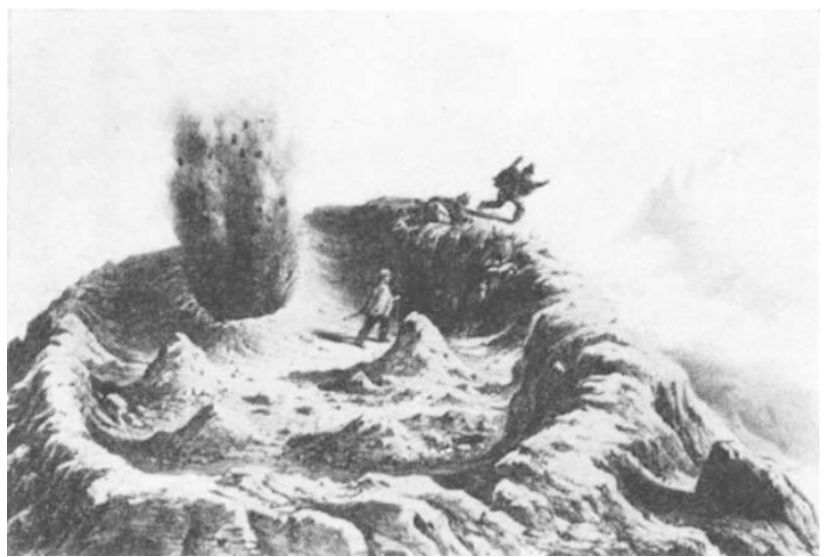

The crater of the volcano of Antuco at the beginning of an eruption, from "Historia fisica y politica de Chile". In Darwin and the Beagle, page 166.

the sea shells prove the land had risen ? FitzRoy, of course, would have none of Darwin's ideas; the sea had risen, not the land, and the fossils were remains of animals excluded from the Ark and drowned in the flood.

Once round Cape Horn, the three pathetic Fuegians who had spent a year or so in Britain, and were, FitzRoy hoped, to civilize their race, landed. Darwin travelled in the Andes while FitzRoy mapped the coast and received bad news from the Admiralty which temporarily turned him mad. Climbing, collecting and exploring, Darwin found sea shells at 12,000 feet above sea level. That, and the rising of the coast line of Chile as a result of a catastrophic earthquake, led Darwin to ask, if the earth could rise a few feet, why not 10,000 feet? By the time the expedition reached the Galapagos Islands in September 1835 Darwin was on the brink of making his revolutionary discovery.

$\mathrm{By}$ the time the Beagle sailed westwards from the Galapagos on the last leg of its voyage, Darwin was sounding out his ideas of evolution on the hostile FitzRoy. But the Beagle was a happy ship homeward bound, a cruise punctuated by diverting landfalls at Tahiti, New Zealand and Australia which served to confirm Darwin in his belief in evolution. On October 2, 1836, after almost five years on the Beagle, Darwin landed at Falmouth, and his only travels outside Britain were over.

Moorehead ends his book with a final chapter on the intervening years until 1859. FitzRoy and Darwin met each other but their friendship cooled; their last meeting in 1857 when FitzRoy stayed at Down House was a failure. The publication of the Origin of Species was for FitzRoy the final straw. At the Oxford meeting of the British Association in 1860, famous for the way in which T. H. Huxley crushed Bishop Wilberforce, a slight grey. haired man armed with a Bible was drowned in the hubbub. Five years later FitzRoy, like his uncle Castlereagh, committed suicide.

Moorehead's book is a triumph of succinct writing, a perfect antidote to the boredom of Boxing Day. One is left wishing he had written twice as much.

\section{JoHN TOOzE}

\section{RECORDS OF THE IRON AGE}

\section{Iron Age Cultures in Zambia}

Vol. 2: Dambwa, Ingombe Ilede and the Tonga. By Brian M. Fagan, D. W. Phillipson and S. G. H. Daniels. (The Robins Series, No. 6.) Pp. xiv $+270+16$ plates. (Chatto and Windus: London, 1969.) $100 s$.

No serious student of the African Iron Age can afford to be without this volume and its precursor, the Iron Age
Cultures in Zambia, Vol. 1, published in 1967, or at least have ready access to them in a library.

The first part of the book concerns the mid-first millennium AD occupation site at Dambwa, a settlement on tho banks of the Zambesi, near Livingstone, whose isolated self-sufficiency contrasts with the elaborate trading network established by the later population of Ingombe Ilede, a site close to the confluence of the Zambesi and Lusitu rivers. It is to be regretted that it was not found practicable to include the latest radiocarbon dates of charcoal excavated at Ingombe Ilede in 1968, which have indicated a hitherto unsuspected second phase of occupation to which the sumptuous burials belong (ref. 1, GX. 1368, $\mathrm{AD} 1340 \pm 85 \mathrm{yr}$ and $G X-1369$, $\mathrm{AD} 1445 \pm 85 \mathrm{yr}$ ). These dates tend to confirm the evidence deduced from the obscrved similarities between the ceremonial iron objects from Ingombe Ilede and the Congo (compare page 102) and from the microscopic analysis of the glass beads (compare page 252). It would now seem that the peak of the trading activities of the population of Ingombe Ilede coincided with the rapid expansion of Arab (hardly "Moorish"?) trading on the east coast of Africa.

During their report on the excavations at Dambwa, Phillipson and Daniels described (page 38) two clay specimens (a tuyère and a funnel) as iron smelting equip. ment. Because, as they themselves say, the tuyère is "almost identical to specimens which we have seen used among the Lunda of the Mwinilunga district in the extreme north-west of Zambia, for smithing", and because there seems to be no evidence for iron smelting furnaces, it would seem that a case could equally well be advanced for the presence of blacksmithing. When there is no provision for the tapping of slag during the process of smelting, the prills of iron become deeply embedded in the bloom. The smith must break the bloom to obtain the iron and therefore it will be at or near the smithy or forge that a concentration of slag can be expected. It is interesting to note (page 7) that a "densely packed concentration of iron slag" occurs at the southern end of a daga floor, in Trench II. It is tempting to conjecture that this floor may represent the remains of a smithy.

The very competent illustrations of the ceramic material give an admirably clear indication of the variety of form and decoration, though in the discussion of the affinities of the Ingombe Ilede pottery, illustrations of the comparative material quoted by Fagan would have greatly contributed to the reader's understanding of the comparison, though no doubt further published studies will help to clarify this.

Nevertheless, the thoroughness and accuracy with which all aspects of the study of Zambia's Iron Age have been investigated make this a most welcome and valuable contribution to the general study of the African Iron Age. BERNARD FAGG

1 Fagan, B., and Phillipson, D. W., J. Afr. Hist., 10 (2), 199 (1969).

\section{LEGEND OF A CATACLYSM}

The End of Atlantis

New Light on an Old Legend. By J. V. Luce. (New Aspects of Antiquity.) Pp. 224+114 plates. (Thames and Hudson: London, May 1969.) $63 s$.

\section{Atlantis}

The Truth Behind the Legend. By A. G. Galanopoulos and Edward Bacon. Pp. $216+24$ colour plates. (Nelson: London, September 1969.) $70 \mathrm{~s}$.

Voyage to Atlantis

A First Hand Account of the Scientific Expedition to Solve the Riddle of the Ages. By James W. Mavor, jun. Pp. $320+32$ plates. (Souvenir Press: London, July 1969.) 42s.

THE legend of Lost Atlantis contains just those ingredients calculated to appeal to the fertile imagination. Great 